\title{
The Role of University Library on the Mathematic Information Quality Education for the Mathematic Graduate Students
}

\author{
Fang Yuan ${ }^{1}$ and Tao Liü* \\ ${ }^{1}$ School of Mathematical Sciences, Qufu Normal University, Qufu 273165, Shandong, China \\ ${ }^{2}$ Department of Chemistry and Chemical Engineering, Jining University, Qufu 273155, Shandong, \\ China \\ amathyf@126.com, bliutao_2005@126.com
}

Keywords: Information quality education; Disciplinization knowledge service; Graduate students; Library

\begin{abstract}
Information quality education has become the important component of the graduate students' education. How to study the information quality education thoroughly is an important research topic for the university library. The graduate students' information quality and disciplinization knowledge service can be promoted each other. To cultivate innovation quality of graduate students, graduate students should grasp the basic innovation principles, know the common innovative approach, and determine the innovation target.
\end{abstract}

\section{Introduction}

The concept of information quality is evolved from the skill of document retrieval. The connotation of information quality includes information consciousness quality, information capability quality, and information moral quality. Information consciousness quality is the acute esthesis to information, the judgement and insight to the information value, and the self-awareness to the demand of the information. Information capability quality includes the ability of information technology application, the ability of information search and obtain, and the ability of information organization and analysis. Information moral quality is the sum total of moral rules to follow in the information activity (Wu 2008).

\section{Discussions}

As the professional personnel with high level, mathematic graduate students are the main force of the science and technological innovation. They should have reasonable knowledge structure, various skills, innovative thinking, and innovative ability. The development of the innovative thinking and innovative ability must be based on the good information quality. As the highest level of education system, graduate students' education is the core link of the innovative talents training. Mathematic graduate students' information quality education must service for the development of the innovation ability of graduate students. Information quality education has become the important component of the graduate students' education. Therefore, how to study the information quality education thoroughly is an important research topic for the university library.

In Table 1, we list the investigation on the graduate students' information quality education performed in the five universities. It is not difficult to find the shortcoming in the mathematics graduate students' information quality education, especially in the relative small universities. Therefore, in order to enhance the mathematics graduate students' talent training quality, we must pay more attention to the mathematics graduate students' information quality education. 
Table 1 The investigation on the graduate students' information quality education performed in the five universities

\begin{tabular}{lcccc}
\hline & $\begin{array}{c}\text { Obtaining } \\
\text { information } \\
\text { effectively }\end{array}$ & $\begin{array}{l}\text { Not grasp information } \\
\text { retrieval skill }\end{array}$ & $\begin{array}{l}\text { Not knowing the } \\
\text { electronic resources }\end{array}$ \\
\hline $\begin{array}{l}\text { Beijing } \\
\text { University }\end{array}$ & Normal & $53 \%^{\mathrm{a}}$ & $36 \%$ & $10 \%$ \\
$\begin{array}{l}\text { Shandong } \\
\text { University }\end{array}$ & $51 \%$ & $43 \%$ & $6 \%$ \\
$\begin{array}{l}\text { Shandong } \\
\text { University }\end{array}$ & Normal & $45 \%$ & $35 \%$ & $20 \%$ \\
$\begin{array}{l}\text { Qufu } \\
\text { University }\end{array}$ & normal & $33 \%$ & $31 \%$ & $35 \%$ \\
Jining University & $12 \%$ & $29 \%$ & $59 \%$ \\
\hline
\end{tabular}

${ }^{\mathrm{a}}$ The percentage relative to the sum of the ones under investigation.

Library owns abundant information resources, advanced information technology, professional human resources, and becomes the main base of carrying information quality education for the university. Information retrieval course undertook by library is the important course to implement information quality education. However, information quality education is not the work only for the teachers of information retrieval course, but closely related with other service work in library, e.g. disciplinization knowledge service. On the one hand, graduate students' information quality education is the important content of the disciplinization knowledge service. On the other hand, the enhancement of the graduate students' information quality can promote disciplinization knowledge service to carry out in reverse. The main operating mechanism is the subject librarian system for the disciplinization knowledge service, which will realize the knowledge service at the greatest extent within the scope of discipline.

The disciplinization knowledge possesses the characters of resource integration, service integration, interactivity, and so on, which will make the seamless link among university library discipline resource, user needs, information quality education, subject librarian, and knowledge service. The formed disciplinary knowledge service dynamic interaction system will support the discipline construction and development of university effectively [1]. There are four features for the disciplinization knowledge service facing to the mathematics graduate students' information quality education. The first feature is the property of stage. The different source of students leads to the uneven graduate students' information quality. Therefore, it is necessary to carry out information quality education at stage according to the character of graduate students in the disciplinization knowledge service. The second feature is specialty. In university, the division of user group is in accordance with the discipline and major basically [2]. There exist crowd with similar scientific research, knowledge structure, personality traits, and study habit, in the same subject research field, and they have joint demand to disciplinization knowledge service. Therefore, the disciplinization knowledge service of library should emphasize the character of discipline and major, and supply specialized vertical service based on the subject content according to the discipline and major. The third feature is innovation. In order to cooperate with the development of the mathematic graduate students' information quality education, library should establish project team as the aim of guarantee knowledge flow in the knowledge service, and recombine organization. Library should also carry out the model of key content knowledge integration service and innovate knowledge service according to the knowledge demand of graduate students and knowledge integrated system [3,4]. In addition, library should exploit new-style and demand-driven intelligent disciplinization knowledge service platform by means of the Web 2.0 technology. The third feature is intellectual. Knowledge service is based on the information search and organization, which can support the service of knowledge application and innovation. The disciplinization knowledge service facing graduate students will not only supply explicit knowledge service, but also supply subject tacit 
knowledge mining service, which will urge graduate students to translate tacit knowledge into explicit knowledge, and realize knowledge innovation and scientific research innovation.

The disciplinization knowledge service is a service idea and practice, and the establish of subject librarian system is an important manner to realize disciplinization knowledge service. The job content area of subject librarian is large, and its central task is academic contact and information quality education [5,6]. The disciplinization knowledge service facing graduate students' information quality education should form the service team with "subject" as central and with "subject librarian" as body.

Therefore, we should carry out along the several ways as follows. Talent team construction is the dominating factor for the carrying out of the disciplinization knowledge service. The "three-level" talent team is composed of assist subject librarian (graduate students), subject librarian (the subject of disciplinization knowledge service), and expert-level librarian (external subject expert).

Now, many universities establish subject librarian system, in which librarian is acted as with that with professional background. However, we believe that it could obtain unexpected results by employing graduate students as assist subject librarian. We think that there might exist five possible reasons. Firstly, graduate students own superior cultural accomplishment and level of expertise, and they can feel up to the role of assist subject librarian passing the information quality education. Secondly, the setting of graduate student's subject librarian can urge graduate students to improve information quality themselves, in order to adopt the demand of the position. Thirdly, the students are apt to turn to contemporary for help, so the student staff is easier of access and the information quality education is easier to carry out. Fourthly, the mode of user participation strengthens the experience of graduate students, which will bring about the "experience effect", strengthen the user friendliness of library, and enhance usage rate of library. Fifthly, the setting of graduate student's subject librarian will decrease the service time of librarian, which is in favorable for the extension of other business in library. Assist subject librarian is in responsible for the professional information consultant and simple information processing. On the other hand, the high depth problem will be guided to subject librarian or expert-level subject librarian.

Subject librarian is the main implementer for the disciplinization knowledge service. The quality of subject librarian decides the effect of knowledge service, the level of information quality education, and the image of library. Therefore, subject librarian should possess subject background, extensive intelligence information knowledge, analysis and synthesis ability, and skillful network knowledge. They should gather experience continuously in practice, which can cause them to carry out information quality education at the high-level and get the appreciation of knowledge at the greatest extent. To supply high-quality subject librarian service, library should offer appropriate training chance. In reverse, subject librarian should study professional knowledge positively, improve their cultural quality and professional skill, and seek the most effective knowledge service mode.

As the specialty of disciplinization knowledge service is extensive, any library cannot possess all the professional background staff they required for. In addition, the academic demand for graduate students is strong, and they desire the deeper service, which cannot be satisfied by the subject librarian. Therefore, we should employ subject expert as the expert-level subject librarian for the disciplinization knowledge service, according to the professional background and research area. At the same time, we should perform subject professional knowledge service guidance, and establish subject expert knowledge service system. Subject expert knowledge service makes the most of explicit and tacit knowledge of the subject experts, improve the service quality, and realize maximum for the knowledge benefit.

Disciplinization knowledge service is an important mode for the innovation of university library. We consider that there are three modes for the development of disciplinization knowledge service mode facing to the graduate students' information quality education.

Integrated information quality education mode is the mode that integrating information quality education content in the specialized course teaching. There are the corresponding web pages related the Course Integrated Library Instruction for the university library in America, which encourages teacher bring students to library to perform education on the library resource and electronic resources using in the lesson. The subject librarian should cooperate with teacher, design corresponding seminar as the complementary program objective, and arrange related task for students to search and scientific research 
[7,8]. For example, in University of Maryland, building subject librarian Cossard cooperated with the teacher Dr. Gournay in school of architecture, and constructed a characteristic architecture honores course. The course is based on the EXPO literature resources collected by building library, and emphasize the training the information quality ability for the accomplishment of the course [9]. It can be concluded that the objective of integrated information quality education mode is not only to impart professional knowledge, but also to make students to grasp new knowledge by using the information resources.

In the personalized information quality mode, library should perform the following ways.

Firstly, "three steps teaching mode for information quality education" should be carried out. The first stage is introduction education, in which we should emphasize the library resources and information retrieval knowledge, and train the information consciousness. The second stage is professional information quality education, in which graduate should grasp the basic approach of obtaining and taking advantage of professional literature resources. The third stage is innovation ability training education, in which graduate students can identify and evaluate the information they obtain, integrate the useful information into their own knowledge, and generate the new knowledge.

Secondly, seminar with subject character should be supplied aiming at different professional graduate students. This job should be undertaken by senior subject librarian with related professional background.

Thirdly, supplying different selection scheme aiming at the students with different learning style. Except for the face-to-face lecture, the way of consulting, E-mail, message board on line, and real-time online consultant can be adopted to offer self-service online. Subject librarian should interact with graduate students positively, and offer multi-level individual service.

The role of information quality education on the innovation ability training includes the following aspects [10]. The information quality education contributes to cultivate innovative thinking, enhance independent learning capability, and set up correct innovate idea. To cultivate innovation quality of mathematic graduate students, graduate students should grasp the basic innovation principles, know the common innovative approach, and determine the innovation target.

\section{Summary}

Disciplinization knowledge service is a long-range strategy for the sustainable development of university library. Information quality education is the key point for the university library. Therefore, university library takes full advantage of the superior resources to explore the new mode for conjunction of them, and train more innovative talents.

\section{Acknowledgements}

This work was supported by the Education Scientific Planning Project of Shandong Province, China (No. CBS15011) and Graduate Student Education Innovation Plan in Shandong Province, China (No. SDYC11116).

\section{References}

[1] P. Wu, Quantivative analysis on the research literature about information quality education, Modern Information, 28 (2008) 198-201.

[2] F. Wu, Study on the university library knowledge service facing to subject, Library Research, 8 (2005) 29-31.

[3] W. Zhou and Z. Qian, Disciplinary knowledge service of subject librarian, Documentation, 6 (2005) 87-89.

[4] E. Dogan and K. Tatsuoka, An international comparison using a diagnostic testing model: Turkish students' profile of mathematical skills on TIMSS-R, Educational Studies in Mathematics, 68 (2008) 263-272. 
[5] G. Hardy and S. Corrall. Revisiting the subject librarian: a study of English, law and chemistry, Journal of Librarianship and Information Science, 39 (2007) 79-91.

[6] R. G. Duncan and C. E. Hmelo-Silver, Learning progressions: aligning curriculum, instruction, and assessment, Journal of Research in Science Teaching, 46 (2009) 606-609.

[7] J. Ormondroyd, Course integrated library instruction, (2010) http://www. libraryinstruction.com/course Cooperation projects; Subject service; Subject librarian; Service modelintegrated.html.

[8] B. F. Green, R. D.Bock, L. G. Humphreys, R. L. Linn and M. D. Reckase, Technical guidelines for assessing computerized adaptive tests, Journal of Educational Measurement, 21 (1984) 347-360.

[9] B. Wang, Explore on the Word Expro honors program in Maryland University, Library and Information, 5 (2005) 65-67.

[10] M. Z. Li and C. S. Qu, The training of innovation ability and information quality education on the students, Modern Information, 27 (2007) 197-209. 